shows the high qualities of lucidity and excellent literary style characteristic of her previous work. The value of the text-book for English students has been greatly enhanced by the additions to the bibliography, which have been made by the editor, Dr. Gordon Holmes. In conclusion it may be stated that the high level of excellence secured in the first two volumes has been well maintained, and leaves no doubt that the work, when completed, will be a most important and valuable addition to the English literature of physiology.

\section{ELEMENTARY GEOGRAPHY.}

(I) A First Geography of the British Isles. By W. M. Carey. Pp. vi +r69. (London: Macmillan and Co., Ltd., I9r5.) Price Is. $6 d$.

(2) Bacon's Sixpenny Contour Atlas. North England Edition. Pp. 4r. Southern Wales Edition. Pp. 4I. Lancashire and Yorkshire Edition. Pp. 4r. (London: G. W. Bacon and Co., Ltd., n.d.) Price $6 d$. net each.

(I) $\begin{gathered}\text { HIS book has been written for classes } \\ \text { preparing for preliminary or junior local }\end{gathered}$ examinations of the universities; it begins by considering latitude and longitude, and the climate of Britain is not considered until the last chapter; all this means that a good deal of previous reading and learning is presupposed. There is a large amount of information, much of it interesting and "curious," and it is markedly accurate; but the comparison of particulars and progression in idea which might be expected in a volume of a "First Book of Science" series are largely absent.

Of the eleven chapters which the book contains, eight deal with the geography of as many different regions, while the two first and the last deal with Britain as a whole. An excellent feature is that each chapter is preceded by about half a dozen practical exercises, and is followed by a similar number of questions partly taken from public examinations and partly original. The practical exercises probably supply the reason why the book is included in the series; but it may be doubted whether there are not too many of the type in which the lengths of certain rivers are given in miles and the pupil is asked to draw lines to represent those lengths to scale. As a means of keeping the youngsters quiet this is good, but the geographical value of the work is small, and it does not help them to remember the relative lengths. Notwithstanding its excellent qualities, we are disappointed with the book. The impression is that there are very many facts, but important and unimportant alike appear to receive the same attention.

The index would have been more useful had it been complete; on a page taken at random nine names were indexed and a dozen were not.

With (2) on the market in its several editions, no school, however straitened, can plead that it cannot afford a satisfactory atlas because of the cost. There are few other atlases on the market which at the price are possible rivals. Each edition contains four local maps, showing communications, geology, relief and vegetation, twenty-four regional relief maps, and seven world maps. It is a pity that some of the work is rather rough; in the Lancashire and Yorkshire edition the Aire Gap is shown on one map to be all under five hundred feet, on another map a small part is shown just over five hundred feet, while in a third the greater portion is shown as more than five hundred feet.

\section{OUR BOOKSHELF.}

Citrus Fruits. By Prof. J. E. Coit. Pp. xx+ 520. (New York: The Macmillan Company; Londors: Macmillan and Co., Ltd., I9I5.) Price $8 s .6 d$. net.

THIs work is written by the professor of citriculture of the University of California, where he is also superintendent of the University Agricultural Experiment Station with regard to citrus fruits. The first chapter deals with the history and development of the citrus industry in California from the introduction of European fruit trees and vines by Spanish Jesuit missionaries about I $70 \mathrm{I}$, and traces the industry to the present time, recording the assistance to its upbuilding rendered by the Department of Agriculture, the University of California, and the Chambers of Commerce, which have aided by lectures, experiments, and advertisement, leading up to the practical result, namely, the shipment of 60,000 carloads of fruit in I9I4.

The following chapters deal with the geography and climate of California; the botany of citrus fruits, their varieties and origins; improvement of varieties by breeding, and from "sports"; judging fruits; site and preparation for planting; cultivation, manuring, cover crops; irrigation; pruning and top-working; frost and orchard heating; picking and packing; blemishes and their prevention; manufacture of by-products (citric acid, candied fruit, etc.) ; marketing ; cost and returns; diseases and their control; insect control and fumigation; horticultural inspection and quarantine; legislation.

Budding, even of old trees, is found more successful than grafting. Some of the best varieties of orange (Navel) and lemon (Eureka) are parthenocarpic, and can successfully be planted in large blocks, but most varieties require crosspollination, and some varieties are found not to be congenial pollenisers.

The author considers the selection of "sports" a more likely source of valuable varieties than by hybridising and raising new sorts.

No. 2394, VOL. 96] 